\title{
Ustilago maydis, a Delicacy of the Aztec Cuisine and a Model for Research
}

\author{
Claudia G. León-Ramírez, José Alejandro Sánchez-Arreguín, José Ruiz-Herrera* \\ Departamento de Ingeniería Genética, Unidad Irapuato, Centro de Investigación y de Estudios Avanzados del \\ Instituto Politécnico Nacional, Irapuato, Gto, México \\ Email: ${ }^{*}$ jruiz@ira.cinvestav.mx
}

Received 4 February 2014; revised 11 March 2014; accepted 29 March 2014

Copyright (C) 2014 by authors and Scientific Research Publishing Inc.

This work is licensed under the Creative Commons Attribution International License (CC BY).

http://creativecommons.org/licenses/by/4.0/

c) (i) Open Access

\begin{abstract}
Ustilago maydis is the causal agent of the disease known as corn smut or Huitlacohe; their natural hosts are maize (Zea mays L.) and its putative ancestor teocintle (Zea mays ssp. parviglumis and ssp. mexicana). In México there is an evidence of its use as human food since pre-hispanic times. Huitlacoche is a typical Mexican food with interesting nutritional properties and distinctive flavor. Its use in cuisine is considered as a culinary delicacy in Mexico and several parts of the world and the current consumption is increasing markedly, mainly due to its exclusive flavor different from any other known food. Huitlacoche contains proteins, carbohydrates, fats, minerals and vitamins that contribute to its nutritional value, also it has been reported that it contains proteins with balanced levels of essential amino acids, something which does not occur in corn having a deficiency mostly in lysine. The fungus also contains compounds with antioxidant properties, consequently it can be included in what are now known as nutraceutical foods. Besides its use in the food, this fungus has been used in different kinds of basic investigation, such as DNA recombination, signaling, cell biology, biotrophic plant-pathogen interactions and others. Its characteristics of dimorphism, and the detailed knowledge we have on its pathogenic development, that we describe in detail, make it an ideal subject for the analysis of fungal differentiation, and for the knowledge of the behavior of the highly aggressive plant pathogens that are members of its taxonomic group, the Ustilaginales. In the present communication we make a thorough review of the nutritional characteristics of $U$. maydis, its life cycle, and the molecular bases of its differentiation, morpohogenesis and pathogenicity.
\end{abstract}

\section{Keywords}

Ustilago maydis, Huitlacoche, Nutraceutical, Basidiocarps, Virulence

\footnotetext{
${ }^{*}$ Corresponding author.
} 


\section{Introduction}

Ustilago maydis (DC.) Cda. is a phytopathogenic fungus belonging to the Order Ustilaginales, subphylum Ustilaginomycotina [1] of the phylum Basidiomycota. As it occurs with most Ustilaginales, in nature U. maydis is a host-specific pathogen, being the causal agent of common smut or "huitlacoche" in maize (Zea mays L.), and its possible ancestor, teozintle (Zea mays ssp. parviglumis and ssp. mexicana). Nevertheless, in contrast to other Ustilaginales that are responsible for severe epiphytia in important harvests, $U$. maydis infections are sparse infecting a low number of corn plants. Curiously infected ears are edible, and extremely appreciated as a delicacy in México, and in modern international cuisine (for reviews see [2] [3] and below).

During its common life cycle in nature the fungus displays three different morphologies with distinct additional characteristics: 1) a unicellular haploid yeast-like morphology 2) a dikaryotic mycelial morphology produced by the mating of two sexually compatible yeast-like cells, and 3) a spherical diploid spore. Whereas the yeasts like cells are saprophytic and not virulent, the dikaryotic mycelial form is the invading stage of the fungus. In addition, the teliospore that develops after karyogamy accumulates in the characteristic tumors produced in the infected plant. Teliospores provide the peculiar flavor of the fungus. Teliospore germination occurs outside the host. Its germination involves meiosis with the formation of a septate phragmobasidium that gives rise to four haploid basidiospores that start the life cycle again [4].

Mating in $U$. maydis is a complex (tetrapolar) process, being governed by two mating factors named $a$ and $b$ ([5] see details below). Whereas there are only two $a$ alleles (better designated as idiomorphs): $a 1$ and $a 2$, the number of known $b$ idiomorphs is very large, $c a .30$ [6]. It has been demonstrated that $a$ idiomorphs are involved in cell fusion [7], and $b$ idiomorphs are involved in mycelium development and pathogenesis [8] [9]. In order that mating occurs it is necessary that both partners carried different $a$ and $b$ idiomorphs.

If $U$. maydis is not very important as a pathogen, it has been an important model for the study of different biological aspects fungi. This includes plant pathogenesis, fungal mating and recombination, and fungal genetics, for citing just a few aspects (see [4] [10] [11] and reviews by [3] [12]-[14]). Among its characteristics that have made it an important model of study for different aspects of fungal biology, we may cite the following: 1) the existence of a haploid phase during which the fungus forms compact yeast-like colonies, allowing the use of bacteriological techniques with them; 2) the possibility to construct diploids for analysis of complementation and dominance; 3) its capacity to be genetically transformed; 4) the existence of homologous genetic recombination; 5) the existence of different genetic markers for selection and genetic manipulation; 6) the facility to perform segregation analyses; 7) the capacity to complete its life cycle in a short time in very young maize plants; 8) the possibility to obtain its dimorphic transition in vitro by several processes; 9) the existence of alternative experimental hosts; 10) the possibility to obtain its sexual cycle in vitro (see below), and 11) the advantage that its genome has been fully sequenced, partially annotated, and freely available.

\section{The Characteristics That Make $U$, maydis Important as an Edible Fungus}

Annually in the world, 787 million T of corn (Zea mays) are produced. Mexico is the fourth corn producer in the world [15], and a limited portion of the harvest is projected for the cultivation of an emerging product of more nutritional value.

Native varieties of corn planted in Mexico are better accepted by farmers because they represent certain advantages over improved varieties such as: lower costs of inputs to production, greater ease in handling to stabilize in different climatic conditions, and better adaptation to different qualities of agricultural soils [16]-[18]. Besides, it is important to note is that in recent years a limited part of the harvest has been adapted for obtaining a food source of higher added value: ears infected with $U$. maydis.

Edible mushrooms are highly valued as part of the human diet in many cultures around the world, primarily for their sensory and nutritional qualities. These are preferably consumed in Asia, Europe and Mesoamerica. Also, this culture constitutes a genuine production-consumption association, that has acquired a social, economic and ecological importance worldwide. In addition, it is applied to biotechnological processes at small and large scale for the benefit of the population.

There is evidence that the diversity of the cuisine of corn in México (a long time before the Spanish conquest [19]), resulted in the enrichment of the diet of native populations. In modern times, corn is undoubtedly one of the foods that contribute more to the nutrition of the local population. Accordingly, it has been calculated that in México, an adult consumes an average of $26.3 \mathrm{~g}$ of corn protein and $1022 \mathrm{Kcal}$ daily [20]. This value represents 
a very high percentage of the day intake for an adult based on a diet of $2000 \mathrm{kcal}$ and $56 \mathrm{~g}$ protein [21]. An additional factor that since ancient times accompanied corn as the base of the Indian diet, was a corn byproduct named huitlacoche, also known as Bia'hui' in zapotec [22]. This is no other, than ears infected with $U$. maydis. There are reports showing that this is a fungal food of Mexican origin, being present in the native cuisine since hundreds of years ago [23]. The name "huitlacoche" is given to fresh ears full of galls, galls that may also appear in other meristematic zones of maize plants infected by U. maydis (Figure 1). These galls were considered until recently an undesirable pest in corn in many parts of the world. Nevertheless, from several years to date, ears infected with $U$. maydis became to be considered a food of high nutraceutical value [24] [25], and a delicatessen in the modern world cuisine. In México its most common use is in preparation of tacos and quesadillas [rolled corn flat cakes (tortillas) with different kinds of foods inside], soups, and sauces. In the international cuisine is used to make sauces to accompany different meats such as chicken, beef, pork, fish and others; pizzas, crepes, etc.

In México the production of huitlacoche is in third place of importance after the cultivation of the mushrooms Agaricus bisporus and Pleurotus ostreatus. The major benefits of the use of huitlacoche for nutrition (besides its unique flavor) are its digestibility, high nutritional value and ability to maintain its high content of protein and vitamins even after cooking.

Huitlacoche contains proteins, carbohydrates, fats, minerals and vitamins that contribute to its nutritional value. Also it has been reported to contain proteins with balanced levels of essential amino acids, which does not occur in corn that has a deficiency in lysine. Other compounds identified in the fungus are antioxidants, a useful characteristic for preventing diseases such as arteriosclerosis. As a consequence of this, it has been included in what are now known as nutraceuticals.

It is very important that the public became informed about these biotechnologically emerging foods that contain all the essential components for a balanced diet. In addition they can also be a source of further income for farmers, since in México a corn cob is acquired on the market for 0.20 USD, whereas a corn cob contaminated with huitlacoche is sold at 2.00 USD or more.

\section{Nutritional Value of $U$. maydis}

The nutritional potential of huitlacoche is important, since by the quality and quantity of essential amino acids, it has been recommended by the FAO/WHO/UNU [26]. The protein content of huitlacoche ranges from 11.5 to $16.4 \mathrm{~g} / 100 \mathrm{~g}$ of dry material. Regarding the amino acids that it possesses, they include all the essential ones, noticeably lysine $(2.97 \mathrm{mg} / \mathrm{g})$ [27], an amino acid deficient in corn protein. In addition we may cite some unsaturated fatty acids such as omega-3 linoleic [28] high fiber (16\% - 23.5\%) and low fat (1.6\% - 2.3\%) [28]. Oxidation of these fatty acids results in the formation of certain aldehydes that give huitlacoche a distinctive aroma (hexanal, octanal, decanal, (EE)-deca-2,4-dienal, E-undec-2-enal, and vanillin) [29].

Among the carbohydrates that are found in huitlacoche, from around 27 of which have been fully identified, the most abundant are: glucose, fructose, glycerol, sorbitol and manitol [30] at a concentration of $55.1 \%-66.5 \%$ [28]. Huitlacoche is also rich in vitamins represented by riboflavin, biotin, niacin and folic acid. It also contains

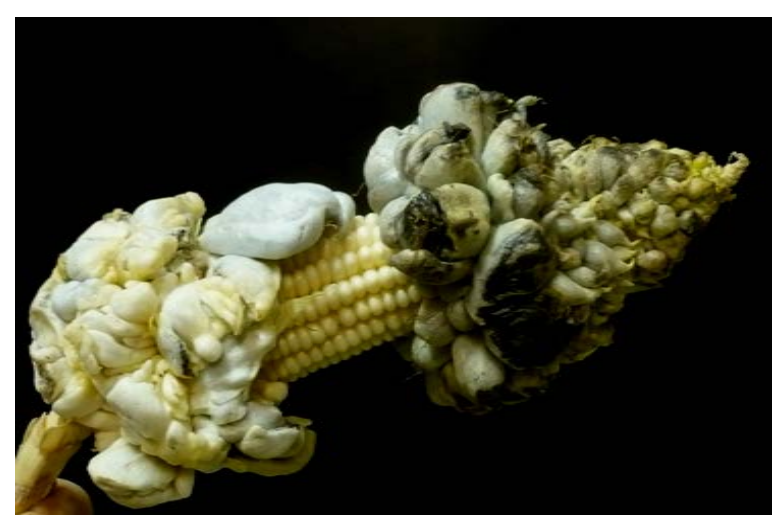

Figure 1. An ear of maize infected with Ustilago maydis showing a number of sori filled with teliospores. 
high percentage of antioxidants [30]. These properties, present when the fungus is in fresh, are kept when in its dehydrated state [31].

\section{The Life Cycles of $U$. maydis}

\subsection{The Normal (Pathogenic) Life Cycle}

As indicated above, the normal life cycle of $U$. maydis in nature involves a pathogenic stage. The haploid cells of $U$. maydis, also known as sporidia, are able to grow indefinitely in vitro in simple synthetic media containing nitrogen and carbon sources plus some salts. Nevertheless, apparently under natural conditions, the fungus is not a competitive colonizer in soil. Growth of sporidia takes place by budding occurring at either pole, pole selection apparently occurring intermittently [32]. The mitotic process is complicated, and different to the mechanism involved in yeast. It involves the movement of the nucleus from the mother to the daughter cell where the nucleus divides, and then one of the products moves back to the mother cell [33]. In nature it is most probable that when teliospores (the form responsible for resistance and dissemination of the species) germinate, there occurs the immediate mating of the sexually compatible sporidia to form a dikaryon. This process depends, as mentioned above, of the idiomorphs $a 1$ and $a 2$ that codify a pheromone/receptor system made by two loci. One of this encoding a pheromone (MFA gene), and the other a receptor (PRA gene) that recognizes the pheromone produced by cells of the opposite sex. Reception of the pheromone by the receptor leads to an increase in the transcription of the genes encoded by the $a$ idiomorph. This creates an autocrine mechanism that leads to stop budding at G2 [34], and the formation of a conjugation tube that grows towards the tip of the conjugation tube made by the mating partner [35]. For some time, arrest of the cell cycle is maintained, interestingly through the effect of Biz1. This is a product of one of the genes controlled by the heterodimer (see below), also involved in the pathogenic cycle of the fungus [36]. After mating, a germination tube is made at the joining point, and the nuclei from both partners move to this newly formed germination tube. Afterwards a septum separates the dikaryon from the mating cells, and growth in the mycelial form takes place. This process can take place on solid media (the so-called Fuz reaction; [37] [38]), and is a form to determine the sex of an unknown strain. Nevertheless, the life of the dikaryotic form is not permanent outside the host, and eventually gives back the haploid forms. This behavior suggests the necessity of some plant signals to maintain the dikaryotic stage of $U$. maydis [39]. By use of specific inhibitors, it has been shown that apical growth of $U$. maydis mycelium requires both microtubules and microfilaments, as occurs with most mycelial fungi. These data have been supported by the observation that kinesin1, and 3 motors are required for apical growth. The dikaryon invades the host through natural openings or in an active way by formation of appressoria. Once inside the plant, the mycelium suffers a series of morphological transformations, to finally form teliospores that by a karyogamy process become diploid. These are liberated after the plant tumors open out, and germinate forming a phragmobasidia, that finally gives rise to four basidiospores that germinate by budding, re-starting the cycle.

\subsection{The Life Cycle Involving Basidiocarp Formation}

As indicated above, mating and genetic recombination of $U$. maydis occur in nature only through the infection of a susceptible host. Nevertheless we devised a system by which maize embriogenic calli covered by a permeable membrane served as a support for mating pairs of sexually compatible strains or diploids of $U$. maydis. In this way it was possible to obtain sexual recombination, although in proportions far from a Mendelian distribution [40]. Also, it was not possible to observe teliospore formation. All mycological textbooks state that Ustilaginales are unable to form fruiting bodies (basidiocarps; e.g. [41]). Nevertheless, based on our previous experiments we were able to define conditions that led to the formation of $U$. maydis basidiocarps in vitro. In synthesis, we grew diploids or mixtures of sexually compatible strains of $U$. maydis on agar plates in the vicinity of maize embriogenic calli, using a medium supplemented with different plant regulators and sucrose [42]. The process required different plant regulators and controlled illumination, and it was inhibited if the callus and the fungus were separated by a non-permeable membrane. These data indicate that diffusible, but not volatile, compounds from the plant, and possibly from the fungus are involved in the process. The structure of the basidiocarps is complex. They are spheroidal and are made of three defined layers, the most internal of which contains holobasidia (contrasting with the phragmobasidia made by geminating teliospores), that give rise to four basidiospores. Genetic analysis demonstrated that meiosis occurred giving the expected product in Mendelian proportions. Basidio- 
spores germinate giving rise to budding sporidia that could follow the pathogenic or the basidiocarp-forming life cycles.

\section{Sexuality and Mating of $U$, maydis}

In most small grain-infecting Ustilago species mating is bipolar, having a single mating locus with two alleles [43] [44]. In contrast, U. maydis mating is tetrapolar, and the fungus contains two sexual loci, one $a$ ) biallelic, and the other $b$ ) multiallelic [5] [6]. As described above, mating only occurs when both alleles (idiomorphs) are different in the mating partners. It has been demonstrated that $a$ loci controls mating and cell fusion [7], and $b$ loci controls filamentous growth and pathogenicity.

$a 1$ and $a 2$ are considered as idiomorphs since they differ in size, and they encode proteins having only a minor sequence similarity [45]. Both idiomorphs contain two open reading frames (ORFs) with similar functions; but $a 2$ contains two additional ORFs of function unrelated to mating. Common in function ORFs correspond to genes denominated MFA, and PRA. MFA genes encode mating factors or pheromones, and PRA genes the receptors of the pheromone synthesized by the opposite mating partner. The pheromones synthesized by $a 1$ and $a 2$ cells are low $\mathrm{Mr}$ peptides, that similarly to mating factors from other fungi, posses the amino acid sequence characteristic of prenylation: CAAX [45], whereas pheromone receptors had similarity to the ones from yeast. The two additional ORFs from $a 2$ correspond to genes $L G A 2$ and RGA2 whose function, were unknown for some time [35], but more recent observations demonstrate that they encode mitochondrial proteins. The function of these proteins is to repress mitochondrial DNA recombination during the sexual phase of the fungus [46]. Binding of the pheromones to their compatible receptors originates a stimulation in the expression of all the genes from the corresponding a locus. A similar stimulatory reaction occurs in the compatible mating partner giving rise to an autocrine reaction between both mating cells, that leads to the formation and growth of conjugation tubes.

The final outcome of the activation of the a loci from the two mating partners is the transmission of the signals through specific signaling cascades, one PKA pathway, and one MAPK pathway [47]-[49]. Transfer of the information from the mating reaction involves a heterotrimeric $G$ protein. From the four $G$ proteins existing in the fungus, only Gp3 is involved in the reaction [50] [51] together with the monomeric small G protein Ras2. The signaling pathway activates a transcription factor named Prf1, that regulates a high number of genes essential for mating, including $a$ and $b$ genes. Activity of Prf1 requires its phosphorylation, but this reaction is distinctly dependent on protein kinases, either Adr1 or the concerted action of Adr1 and Kpp2. In the first case this leads to activation of gene $a$ products, whereas in the second case, activation of $b$ genes takes place [52] [53]. A detailed description of the genes involved in both signaling pathways (and their interaction with Prf1) may be consulted in [54]. In summary, the MAPK pathway involves $U b c 2$, a probable scaffold protein of the pathway, the MAPKKK Kpp4 (Ubc4), the MAPKK Fuz7 (Ubc5), and the MAK Kpp2 (Ubc3). At the end of the cascade $U b c 3$ activates Rop1, and Hap2, and indirectly, Prf1. The PKA signaling pathway involves the adenylate cyclase Uac1, and the cAMP dependent kinase made by the regulatory subunit $U b c 1$, and the catalytic subunit Adr1. Adr1, as described above, is responsible for PrF1 phosphorylation, together with the action of Kpp2 (Ubc3).

Interestingly, basically the same two signaling cascades are involved in the pathogenic process, in this case being activated by external stimuli coming from the host. The final regulatory component that becomes activated in the pathogenic process is the $b E / b W$ heterodimer that regulates the expression of a great number of genes involved in virulence (see below).

The structure of $b$ genes is more complex than that of $a$ alleles, and as would be expected from their large numbers, not all of them have been cloned and sequenced. $b$ alleles encode two genes of different size denominated as $b E$ and $b W$, which are divergently transcribed. Their structure is similar, although they conserve scant homology. They contain a homedomain that separates two regions, one located at the $N$-terminal portion with poor similarity among different $b$ genes, and another one located at the $C$-terminus which is highly conserved [8] [55]. Polar growth and virulence require that a $b E$ product from one of the mating partners forms a heterodimer with a $b W$ product from the other one via their $N$-terminus domains [56]. This heterodimer acts as a master transcriptional regulator of a number of genes that are involved in both of the above-mentioned processes [57].

An additional role of heterodimer formation is the inhibition of further mating with other cells preventing self-fertilization, probably through an inhibition in the expression of locus a products [58], as was experimentally demonstrated by [35]. 


\section{Morphogenesis of $U$, maydis}

During its pathogenic and basidiocarp-forming life cycles, U. maydis suffers noticeable morphological changes, from cigar-shaped yeast-like cells to mycelium, and to spherical spores (teliospores) in one case. In the other life cycle, an extremely complex large spheroidal structure (basidiocarp) is formed where different types of mycelium, and holobasia can be recognized [42]. In general, the mechanisms involved in these morphogenetic processes are unknown, since most of the detailed analyses on the fungus have been directed to elucidate its pathogenic mechanisms. Under natural conditions, as described above, it was shown that filamentous growth requires heterokaryosis of $b$ genes. Nevertheless it has been demonstrated that mycelial growth of $U$. maydis can be induced under different experimental conditions independently of $b$ genes. Thus, growth of heterokaryons in low-nitrogen media can survive and grow in the form of mycelium for long periods of time [39]. Another example is adenylate cyclase minus (uac1) mutants that grow constitutively with a filamentous morphology [59]. Addition of cAMP reversed the effect of the mutation. Using an acid $\mathrm{pH}$ in the growth medium we were able to induce mycelial growth of $U$. maydis haploid cells, mainly if the cells were previously taken to $\mathrm{G}_{0}$ [60]. Similar results were obtained when $b$-minus mutants were used. A further example of filamentous growth independent of the $b$ genes was reported in [61]. The authors observed that fatty acids induced mycelial growth in haploid cells. Further studies pointed out that the multifunctional enzyme involved in $\beta$-oxidation of fatty acids was required for the dimorphic effect of lipids on dimorphism [62].

A role of the two different signal transduction pathways MAPK and PKA on morphogenesis was observed. All mutants affected in members of the MAPK pathway were found to grow in the yeast-like form, independently of the $\mathrm{pH}$ of growth, whereas uac1 and $u b c 1$ mutants grew in the mycelial form at neutral $\mathrm{pH}$ [44]. These results are evidence that the MAPK pathway is required for mycelial growth, whereas the PKA pathway is involved in yeast growth. Further results demonstrated that the mechanisms involved in the effect of $\mathrm{pH}$ on $U$. maydis morphogenesis is unrelated to the $\mathrm{pH}$-responsive general pathway of fungi, the so-called Rim or Pal pathway, since pacC mutants were not affected in their morphogenesis or virulence [63]. Interestingly, data were obtained that polyamines were required for the yeast-to-mycelium transition of $U$. maydis induced by $\mathrm{pH}$ [64], and more recently a requirement of these substances for mating was observed. This requirement was pinpointed to an effect of polyamines on the transcription of MFA genes (unpublished).

To obtain information on the molecular mechanisms involved in the dimorphic transition of $U$. maydis induced by a $\mathrm{pH}$ change, we proceeded to identify the genes regulated during the process using microarrays. To distinguish between the genes specifically involved in dimorphism from those dependent on $\mathrm{pH}$, or other variable we used two monomorphic strains, one growing constitutively in the yeast form and the other as mycelium. In these experiments we identified 154 genes specifically involved in the yeast-to-mycelium dimorphic transition, 82 up-regulated, and 72 inhibited. The functional characterization of these genes revealed that metabolism, transport and cellular communication, and stress, cell differentiation and biogenesis of cellular components were the classes more represented [65]. Interestingly, 22 genes differentially regulated by change in $\mathrm{pH}$ were found to be regulated by the $b$ heterodimer. In a companion study focused on the genes encoding proteins involved in wall synthesis and from the secretome [66] it was observed that a number of genes involved in $\beta$-glucan synthesis, chitin synthesis, deacetylases and secreted proteins were up-regulated. These results indicated that important changes in cell wall formation occur during morphogenesis of the fungus.

\section{The Pathogenic Characteristics of $U$, maydis}

\subsection{Infection of the Natural Host, Maize}

It is known that only heterokaryons and diploids of $U$. maydis are virulent to their natural hosts. Acccordingly, an intense investigation on the pathogenicity mechanisms of them has taken place in the recent years (for a review of this matter see [54]).

For some time it has been considered that the plant host must produce some signals to the fungus that induce the invasion process. Accordingly, it has been shown that hydrophobicity of the plant surface, and some components of cutin, like hydroxy fatty acids stimulate appressoria formation [67]. This process requires phosphorylation of Kpp2, but the detailed mechanism of response of the fungus, that would include the probable formation of degrading enzymes, are still tentative.

As already mentioned, virulence of the fungus requires that invading hyphae contain compatible $a$ and $b$ 
genes, the latter of which gives rise to the formation of a heterodimer (see above). This heterodimer operates as the master transcriptional regulator for mycelial growth and virulence (see [54]). Microarray analyses revealed that the number of genes controlled by the $b$ locus were 347; 212 up-regulated, and 135 down-regulated [68]. This regulation, rather than being strictly direct, depends on the regulation of a set of additional transcription factors. One of these, a $\mathrm{C}_{2} \mathrm{H}_{2}$ zinc finger protein denominated Rbf1, was described as a master regulator necessary for the up-regulation of $90 \%$ of the genes under the positive control of the heterodimer. Evidence has been provided that this in turn activates three transcription factors: Kpp6, Biz1, and Hdp1 [69].

Under natural conditions the mycelial stage of the fungus infects the host, getting access into their tissues through natural openings mainly stigma and stomata, but also wounds [70] [71]. Neverteheless, more recent evidence demonstrates that previous to invasion, growth of invading hyphae stops, their tips engross and appressoria are formed that penetrate into the plant tissues [54]. Formation of appressoria depends on the activity of the MAPK Kpp6 [72], and the heterodimer-controlled transcription factor Biz1 [36]. It has been suggested that penetration of appressoria into the host tissues requires the action of lytic enzymes. These enzymes destroy the components present on the surface of the plant tissues. Paradoxically, the number of lytic enzymes in the fungal secretome is particularly scant when compared with that of necrotrophic phytopathogenic fungi [2] [73].

Considering the importance of the cell wall in the structure of the fungi, $U$. maydis not being an exception, it is not surprising that interest in the mechanism of synthesis of the cell wall of this fungus was aroused in several groups. Their research has been directed to determine whether some enzymes involved in the synthesis of the cell wall of $U$. maydis are required for its pathogenic behavior. We now know that $U$. maydis contains 8 genes encoding chitin synthases. The first two genes to be isolated showed not to be required for pathogenesis [74]. The same occurred with the following three genes: Chs3, Chs4 and Chs5, that we have cloned and disrupted [75] [76]. These data suggested that the role of the different chitin synthases was redundant. However, later on we demonstrated that mutation of Chs6 gene made the fungus completely non-virulent, indicating that it synthesized most of the polysaccharide during infection of maize [77]. Additional experiments demonstrated that Chs8 was also required for full pathogenesis of $U$. maydis [78]. Of course not only chitin is required for virulence of the fungus. Thus it was demonstrated that Pmt4, a member of the group of O-mannnosyltransferases involved in protein glycosylation was required for $U$. maydis appressorium formation, and penetration into the plant, but not at other stages of growth [79]. More recently, we obtained preliminary evidence that mutation of a chitin deacetylase led to decreased virulence of $U$. maydis [80]. Chitin deacetylases are enzymes that transform chitin into chitosan, an important polysaccharide of the fungal cell wall.

As occurs with plant infection by a number of phytopathogenic fungi, U. maydis produces a number of socalled effectors. These are products with no conserved functional domains that interact with the defense mechanisms of the host, facilitating their invasion. In the case of $U$. maydis, it was shown that the genes encoding effectors are organized in 12 clusters, 5 of which are directly related to virulence [81]. One of the first effectors identified in $U$. maydis was Pep1 whose mutation led to a complete resistance of maize to infection [82]. Interestingly, it was demonstrated that Pep1 interfered with the response to the infection through $\mathrm{H}_{2} \mathrm{O}_{2}$ production by inhibition of the plant peroxidase activity [83]. A cluster named Pit, made of 4 genes, encoding possible effectors was further described [84]. Mutation of this cluster led to drastic reduction in virulence of $U$. maydis in maize. The inhibitory effect on virulence by the cluster was pinpointed to Pit1 and Pit2, being suggested to inhibit plant responses to infection.

Once in the interior of the host, fungal hyphae suffer a series of discrete morphological alterations that finally lead to the formation of teliospores. These morphological alterations were described with impressive detail by Bannuet and Herskowitz [85]. The authors showed that after infection, U. maydis mycelium branched abundantly in the plant tissues. At a later stage they became covered by a mucilaginous matter and became separated into deformed cells. These filled enlarged plant cells that appeared as "sacs full of worms" according to the description of these authors. Finally, the cells were covered by a thick wall, rounded up, and their surface appeared echinulated and turned dark brown, representing the maturation step of the teliospores. During the process, karyogamy takes place, probably at the time of mucilage formation, and teliospores become diploid. Also, along with these stages, the external symptoms of the disease are observed: tissues become chlorotic, anthocyanins are accumulated, and tumors, the most characteristic hallmark of the disease, develop. The authors presented evidence that the first stage in the formation of tumors coincided with the increased branching of the mycelium. In the final stages of the disease, teliospores fill up the plant tumors. Interestingly, the authors described that infectious process by sexually heterozygous diploids occurred exactly the same as occurs in the process described for 
heterokaryons.

Progress of the infection requires the interplay of distinct gene products that are under the control of both, MAPK and PKA signaling pathways. For example, it has been demonstrated that Hgl1, a target of the PKA pathway is essential for teliospore maturation, and that DP1 gene is essential for $U$. maydis development in the plant, and for the formation of clamp connections, an event necessary for correct nuclear distribution [54].

It is interesting to note that no data on the infection of the other natural host (teozintle) have been reported.

\subsection{Infection of Alternative Hosts under Axenic Conditions}

The use of alternative hosts has been a tool widely used in the study of infectious diseases, ever since the initial days of the discovery of the microbial nature of transmissible diseases. Their advantages are so many and of such importance, that it appears unnecessary to discuss them here. Although under natural conditions $U$. maydis is able to infect maize and teozintle exclusively, it was demonstrated that under axenic conditions it was able to infect a great number of plant species [86] [87]. In these plants, the main symptoms observed included abundant growth of the fungus in the plant tissues, development of chlorosis, production of anthocyanins, and in some species, development of malformations or adventitious roots. However, in none of them the sexual cycle occurred, demonstrating the specific requirement of the natural hosts for this process to occur. Interestingly, the infection of alternative hosts could be brought about by diploids and haploid as well. Deeper analyses on the $U$. maydis/Arabidopsis thaliana pathosystem revealed that whereas the diploid behaved as a biotrophic pathogen, the haploid behaved as a necrotrophic one. During the change from a saprophytic lifestyle to invasion of the plant, a great number of genes (3537/3299), similar to the numbers described for maize infection, became differentially regulated as determined by microarray analyses [88]. Regulation of some genes normally under the control of the $b$ heterodimer appeared being regulated by infection with the haploid. This observation suggests the existence of alternative regulation mechanisms. Interestingly, a large number of genes regulated during maize infection, were also regulated during the experimental infection of Arabidopsis. This indicates the parallelism of both processes, and the advantages of the use of experimental hosts in the study of the molecular bases of $U$. maydis pathogenicity.

\section{Acknowledgements}

This work, and the experimental work made by the authors here reported, were supported by Consejo Nacional de Ciencia y Tecnología (CONACYT), México.

\section{References}

[1] James, T.Y., Kauff, F., Schoch, C.L., et al. (2006) Reconstructing the Early Evolution of the Fungi Using a Six Gene Phylogeny. Nature, 443, 818-822. http://dx.doi.org/10.1038/nature05110

[2] Ruiz-Herrera, J., Reynaga-Peña, C.G. and Aréchiga-Carvajal, E.T. (2008) Ustilago maydis as a Model for Phytopathogenic Fungal Development. In: Khachatourians, G.G., Arora, D.K., Rajendran, T.P. and Srivastava, A.K., Eds., Agriculturally Important Microorganisms (Vol. 1), Academic World, Bhopal, 107-122.

[3] Ruiz-Herrera, J. and León-Ramírez, C.G. (2012) Development and Dimorphism of the Pathogenic Basidiomycota Ustilago maydis. In: Ruiz-Herrera, J., Ed., Dimorphic Fungi: Their Importance as Models for Differentiation and Pathogenesis, Bentham E Books, 105-116.

[4] Holliday, R. (1974) Ustilago maydis. In: King, R.C., Ed., Handbook of Genetics (Vol. 1), Plenum, New York, 575595.

[5] Rowell, J.B. (1955) Functional Rate of Compatibility Factors and an in Vitro Test for Sexual Compatibility with Haploid Lines of Ustilago zeae. Phytopathology, 45, 370-374.

[6] Puhalla, J.E. (1970) Genetic Studies of the $b$ Incompatibility Locus of Ustilago maydis. Genetics Research, 16, 229-232. http://dx.doi.org/10.1017/S0016672300002457

[7] Trueheart, J. and Herskowitz, I. (1992) The a Locus Governs Cytoduction in Ustilago maydis. Journal of Bacteriology, 174, 7831-7833.

[8] Kronstad, J.W. and Leong, S.A. (1990) The $b$ Mating Type Locus of Ustilago maydis Contains Variable and Constant Regions. Genes \& Development, 4, 1384-1395. http://dx.doi.org/10.1101/gad.4.8.1384

[9] Wangemann-Budde, M. and Schauz, K. (1991) Intraspecific Hybridization of Ustilago maydis Haploids with Compati- 
ble and Incompatible Mating Type by Electrofusion and Genetic Analysis of Fusion Products. Experimental Mycology, 15, 159-166. http://dx.doi.org/10.1016/0147-5975(91)90016-7

[10] Christensen, J.J. (1963) Corn smut Caused by Ustilago maydis. In: American Phytopathology Society Monograph No. 2, American Phytopath Soc., Saint Paul, 1-41.

[11] Holliday, R. (1961) Induced Mitotic Crossing-Over in Ustilago maydis. Genetics Research, 2, 231-248. http://dx.doi.org/10.1017/S0016672300000720

[12] Martínez-Espinoza, A.D., García-Pedrajas, M.D. and Gold, S.E. (2001) The Ustilaginales as Plant Pests and Model Systems. Fungal Genetics and Biology, 35, 1-20. http://dx.doi.org/10.1006/fgbi.2001.1301

[13] Ruiz-Herrera, J., León-Ramírez, C. and Martínez-Espinoza, A.D. (2000) Morphogenesis and Pathogenesis in Ustilago maydis. Recent Research Developments in Microbiology, 4, 585-596.

[14] Ruiz-Herrera, J., Ortiz-Castellanos, L., Martínez, A.I., et al. (2008) Analysis of the Proteins Involved in the Structure and Synthesis of the Cell Wall of Ustilago maydis. Fungal Genetics and Biology, 45, 571-576. http://dx.doi.org/10.1016/j.fgb.2008.04.010

[15] Consejo Nacional de Ciencia y Tecnología. Sistema de Fondos FINNOVA. Fondo: C0009 Convocatoria: C0009-201202 Solicitud: 000000000191903 Modalidad: A5.

[16] Guillén-Pérez, L.A., Sánchez-Quintanar, C., Mercado-Domenech, S. and Navarro Garza, H. (2002) Análisis de atribución causal en el uso de semilla criolla y semilla mejorada de maíz. Agrociencia, 36, 377-387.

[17] Turiján-Altamirano, T., Damián-Huato, M.A., Ramírez-Valverde, B., et al. (2012) Manejo tradicional e innovación tecnológica en cultivo de maíz en San José Chiapa, Puebla. Revista Mexicana de Ciencias Agrícolas, 3, 1085-1110.

[18] Turrent-Fernández, A., Wise, T.A. and Garvey, E. (2012) Factibilidad de alcanzar el potencial productivo de maíz de México. Mexican Rural Development Research Reports, 24, 1-36.

[19] Echeverría, M.E. and Arroyo, L.E. (2000) Recetario del Maíz. Cocina Indígena y Popular. Consejo Nacional para las Culturas y las Artes (CONACULTA), México D.F., 441.

[20] FAOSTAT (2009) Food Supply. Crops Primary Equivalent. Data Base. http://faos-tat3.fao.org/home/index.html

[21] Serna-Saldívar, S.O. and Amaya-Guerra, C.A. (2008) El papel de la tortilla nixtamalizada en la nutrición y la alimentación. In: Rodríguez-García, M.E., Serna-Saldívar, S.O. and Sánchez-Sinencio, F., Eds., Nixtamalización: del Maíz a la Tortilla. Aspectos Nutrimentales y Toxicológicos, Universidad Autónoma de Querétaro, Querétaro, 105-151.

[22] Garibay-Orijel, R. (2009) The Zapotec Names for Fungi. Revista Mexicana de Micología, 30.

[23] Valadez-Azúa, R., Moreno Fuentes, A. and Gómez Álvarez, G. (2011) Cujtlacochi. El Cuitlacoche. IIA-UNAM. México D.F., 138 p.

[24] Beas, F.R., Loarca, G., Guzmán, S.H., Rodriguez, M.G., Vasco, N.L. and Guevara, F. (2011) Potencial nutracéutico de componentes bioactivos presentes en huitlacoche de la zona centro de México. Revista Mexicana de Ciencias Farmacéuticas, 42, 36-44.

[25] Juárez-Montiel, M., Ruiloba de León, S., Chávez-Camarillo, G., Hernández-Rodríguez, C. and Villa-Tanaca, L. (2011) Huitlacoche (Corn Smut), Caused by the Phytopathogenic Fungus Ustilago maydis, as a Functional Food. Revista Iberoamericana de Micología, 28, 69-73. http://dx.doi.org/10.1016/j.riam.2011.01.001

[26] FAO/WHO/UNU (1985) Energy and Protein Requirements. Report of a Joint FAO/WHO/UNU Expert Consultation. WHO Technical Report Series, No. 724.

[27] Lizárraga-Guerra, R. and López, M.G. (1996) Content of Free Amino Acids in Huitlacoche (Ustilago maydis). Journal of Agricultural and Food Chemistry, 44, 2556-2559. http://dx.doi.org/10.1021/jf960017u

[28] Valverde, M.E., Paredes-López, O., Pataky, J.K., Guevara-Laraa, F. and Pineda, T.S. (1995) Huitlacoche (Ustilago maydis) as a Food Source-Biology, Composition, and Production. Critical Reviews in Food Science and Nutrition, 35, 191-229. http://dx.doi.org/10.1080/10408399509527699

[29] Lizárraga-Guerra, R., Guth, H. and López, M.G. (1997) Identification of the Most Potent Odorants in Huitlacoche (Ustilago maydis) and Austern Pilzen (Pleurotus sp.) by Aroma Extract Dilution Analysis and Static Head-Space Samples. Journal of Agricultural and Food Chemistry, 45, 1329-1332. http://dx.doi.org/10.1021/jf960650f

[30] Lizárraga-Guerra, R. (1995) Extracción y caracterización de compuestos saborizantes en huitlacoche (Ustilago maydis) Tesis de maestría. Universidad Autónoma de Sinaloa, 30-34, 57-70.

[31] Lobato-Salinas, V., Martínez-Flores, H., Lucas-Huacuz, S., et al. (2010) Alternativa tecnológica para el uso del hongo huitlacoche (Ustilago maydis) Subdirección de Innovación y Apropiación de Tecnologías para el Desarrollo del Centro de Investigación y Desarrollo del Estado de Michoacán. Calzada Juárez 1446, Col. Villa Universidad, C.P. 58060, Morelia, Michoacán.

[32] Jacobs, C.W., Mattichak, S.J. and Knowles, J.F. (1994) Budding Patterns during Cell Cycle of the Maize Smut Patho- 
gen Ustilago maydis. Canadian Journal of Botany, 72, 1675-1680. http://dx.doi.org/10.1139/b94-205

[33] Snetselaar, K.M. (1993) Microscopic Observation of Ustilago maydis Mating Interactions. Experimental Mycology, 17, 345-355. http://dx.doi.org/10.1006/emyc.1993.1033

[34] Garcia-Muse, T., Steinberg, G. and Perez-Martin, J. (2003) Pheromone-Induced G 2 Arrest in the Phytopathogenic Fungus Ustilago maydis. Eukaryotic Cell, 2, 494-500. http://dx.doi.org/10.1128/EC.2.3.494-500.2003

[35] Urban, M., Kahmann, R. and Bölker, M. (1996) Identification of the Pheromone Response Element in Ustilago maydis. Molecular and General Genetics, 251, 31-37.

[36] Flor-Parra, I., Vranes, M., Kämper, J. and Pérez-Martín, J. (2006) Biz1, a Zinc Finger Protein Required for Plant Invasion by Ustilago maydis, Regulates the Levels of a Mitotic Cyclin. Plant Cell, 18, 2369-2387. http://dx.doi.org/10.1105/tpc.106.042754

[37] Day, P.R. and Anagnostakis, S.L. (1971) Corn Smut Dikaryon in Culture. Nature, 231, 19-20. http://dx.doi.org/10.1038/newbio231019a0

[38] Banuett, F. and Herskowitz, I. (1989) Different Alleles of Ustilago maydis Are Necessary for Maintenance of Filamentous Growth but Not for Meiosis. Proceedings of the National Academy of Sciences of the United States of America, 86, 5878-5882. http://dx.doi.org/10.1073/pnas.86.15.5878

[39] Banuett, F. and Herskowitz, I. (1994b) Morphological Transitions in the Life Cycle of Ustilago maydis and Their Genetic Control by the $a$ and $b$ Loci. Experimental Mycology, 18, 247-266. http://dx.doi.org/10.1006/emyc.1994.1024

[40] Ruiz-Herrera, J., León-Ramírez, C., Cabrera-Ponce, J.L., Martínez-Espinoza, A.D. and Herrera-Estrella, L. (1999) Completion of the Sexual Cycle and Demonstration of Genetic Recombination of Ustilago maydis in Vitro. Molecular and General Genetics, 262, 468-472. http://dx.doi.org/10.1007/s004380051107

[41] Alexopoulous, C.J. and Mims, C.W. (1979) Introductory Mycology. 3rd Edition, John Wiley and Sons, New York.

[42] Cabrera-Ponce, J.L., León-Ramírez, C.G., Verver-Vargas, A., Palma-Tiradob, L. and Ruiz-Herrera, J. (2012) Metamorphosis of the Basidiomycota Ustilago maydis: Transformation of Yeast-Like Cells into Basidiocarps. Fungal Genetics and Biology, 49, 765-767. http://dx.doi.org/10.1016/j.fgb.2012.07.005

[43] Thomas, P.L. (1991) Genetics of Small Grain Smuts. Annual Review of Phytopathology, 29, 137-148. http://dx.doi.org/10.1146/annurev.py.29.090191.001033

[44] Martínez-Espinoza, A.D., Ruiz-Herrera, J., León-Ramírez, C. and Gold, S.E. (2004) MAP Kinase and cAMP Signaling Pathways Modulate the pH-Induced Yeast-to-Mycelium Dimorphic Transition in the Corn Smut Ustilago maydis. Current Microbiology, 49, 274-281. http://dx.doi.org/10.1007/s00284-004-4315-6

[45] Bölker, M., Urban, M. and Kahmann, R. (1992) The a Mating Type Locus of U. maydis Specifies Cell Signaling Components. Cell, 68, 441-450. http://dx.doi.org/10.1016/0092-8674(92)90182-C

[46] Fedler, M., Luh, K.S., Stelter, K., Nieto-Jacobo, F. and Basse, C.W. (2009) The a2 Mating-Type Locus Genes lga2 and rga2 Direct Uniparental mtDNA Inheritance and Constrain Mitochondrial DNA Recombination during Sexual Development of Ustilago maydis. Genetics, 181, 847-860. http://dx.doi.org/10.1534/genetics.108.096859

[47] Garcia-Pedrajas, M.D., Nadal, M., Bölker, M., Gold, S.E. and Perlin, M.H. (2008) Sending Mixed Signals: Redundancy vs. Uniqueness of Signaling Components in the Plant Pathogen, Ustilago maydis. Fungal Genetics and Biology, 45, S22-S30. http://dx.doi.org/10.1016/j.fgb.2008.04.007

[48] Klosterman, S.J., Perlin, M.H., Garcia-Pedrajas, M., Covert, S.F. and Gold, S.E. (2007) Genetics of Morphogenesis and Pathogenic Development of Ustilago maydis. Advances in Genetics, 57, 1-47. http://dx.doi.org/10.1016/S0065-2660(06)57001-4

[49] Nadal, M., García-Pedrajas, M.D. and Gold, S.E. (2008) Dimorphism in Fungal Plant Pathogens. FEMS Microbiology Letters, 284, 127-134. http://dx.doi.org/10.1111/j.1574-6968.2008.01173.x

[50] Regenfelder, E., Spellig, T., Hartmann, A., Lauenstein, S., Bölker, M. and Kahmann, R. (1997) G Proteins in Ustilago maydis: Transmission of Multiple Signals. EMBO Journal, 16, 1934-1942. http://dx.doi.org/10.1093/emboj/16.8.1934

[51] Krüger, J., Loubradou, G., Regenfelder, E., Hartmann, A. and Kahmann, R. (1998) Crosstalk between cAMP and Pheromone Signalling Pathways in Ustilago maydis. Molecular and General Genetics, 260, 193-198. http://dx.doi.org/10.1007/s004380050885

[52] Kaffarnik, F., Müller, P., Leibundgut, M., Kahmann, R. and Feldbrügge, M. (2003) PKA and MAPK Phosphorylation of Prf1 Allows Promoter Discrimination in Ustilago maydis. EMBO Journal, 22, 5817-5826. http://dx.doi.org/10.1093/emboj/cdg554

[53] Müller, P., Weinzierl, G., Brachmann, A., Feldbrügge, M. and Kahmann, R. (2003) Mating and Pathogenic Development of the Smut Fungus Ustilago maydis Are Regulated by One Mitogen-Activated Protein Kinase. Eukaryotic Cell, 2, 1187-1199. http://dx.doi.org/10.1128/EC.2.6.1187-1199.2003 
[54] Brefort, T., Doehlemann, G., Mendoza-Mendoza, A., Reissman, S., Djamei, A. and Kahmann, R. (2009) Ustilago maydis as a Pathogen. Annual Review of Phytopathology, 47, 423-445. http://dx.doi.org/10.1146/annurev-phyto-080508-081923

[55] Schulz, B., Banuett, F., Dahl, M., Schlesinger, R., Schäfer, W., Martin, T., Herskowitz, I. and Kahmann, R. (1990) The $b$ Alleles of $U$. maydis Whose Combinations Program Pathogenic Development, Code for Polypeptides Containing a Homeodomain-Related Motif. Cell, 60, 295-306. http://dx.doi.org/10.1016/0092-8674(90)90744-Y

[56] Gillissen, B., Bergmann, J., Sandman, C., Schroeer, B., Bölker, M. and Kahmann, R. (1992) A Two Component Regulatory System for Self/Non-Self Recognition in U. maydis. Cell, 68, 647-657. http://dx.doi.org/10.1016/0092-8674(92)90141-X

[57] Kämper, J., Reichmann, M., Romeis, T., Bölker, M. and Kahmann, R. (1995) Multiallelic Recognition: Nonself-Dependent Dimerization of the bE and bW Homeodomain Proteins in Ustilago maydis. Cell, 81, 73-83. http://dx.doi.org/10.1016/0092-8674(95)90372-0

[58] Laity, C., Giasson, L., Campbell, R. and Kronstad, J. (1995) Heterozygosity at the $b$ Mating-Type Locus Attenuates Fusion in Ustilago maydis. Current Genetics, 27, 451-459. http://dx.doi.org/10.1007/BF00311215

[59] Gold, S., Duncan, G., Barret, K. and Kronstad, J. (1994) cAMP Regulates Morphogenesis in the Fungal Pathogen Ustilago maydis. Genes \& Development, 8, 2805-2816. http://dx.doi.org/10.1101/gad.8.23.2805

[60] Ruiz-Herrera, J., León, C.G., Guevara-Olvera, L. and Cárabez-Trejo, A. (1995) Yeast-Mycelial Dimorphism of Haploid and Diploid Strains of Ustilago maydis. Microbiology, 141, 695-703. http://dx.doi.org/10.1099/13500872-141-3-695

[61] Klose, J., Moniz de Sá, M. and Kronstad, J.W. (2004) Lipid-Induced Filamentous Growth in Ustilago maydis. Molecular Microbiology, 52, 823-835. http://dx.doi.org/10.1111/j.1365-2958.2004.04019.x

[62] Klose, J. and Kronstad, J.W. (2006) The Multifunctional Beta-Oxidation Enzyme Is Requiered for Full Symptom Development by the Biotrophic Maize Pathogen Ustilago maydis. Eukaryotic Cell, 5, 2047-2061. http://dx.doi.org/10.1128/EC.00231-06

[63] Aréchiga-Carvajal, E.T. and Ruiz-Herrera, J. (2005) The RIM101/pacC Homologue from the Basidiomycete Ustilago maydis Is Functional in Multiple pH-Sensitive Phenomena. Eukaryotic Cell, 4, 999-1008. http://dx.doi.org/10.1128/EC.4.6.999-1008.2005

[64] Guevara-Olvera, L., Xoconostle-Cazares, B. and Ruiz-Herrera, J. (1997) Cloning and Disruption of the Ornithine Decarboxilase Gene in Ustilago maydis: Evidence for the Role of Polyamines in Its Dimorphic Transition. Microbiology, 143, 2237-2245. http://dx.doi.org/10.1099/00221287-143-7-2237

[65] Martínez-Soto, D. and Ruiz-Herrera, J. (2013) Transcriptomic Analysis of the Dimorphic Transition of Ustilago maydis Induced in Vitro by a Change in pH. Fungal Genetics and Biology, 58-59, 116-125. http://dx.doi.org/10.1016/j.fgb.2013.08.011

[66] Robledo-Briones, M. and Ruiz-Herrera, J. (2013) Regulation of Genes Involved in Cell Wall Synthesis and Structure during Ustilago maydis Dimorphism. FEMS Yeast Research, 13, 74-84. http://dx.doi.org/10.1111/1567-1364.12011

[67] Mendoza-Mendoza, A., Djamei, A., Weise, C., Linne, U., Marahiel, M., Vraneš, M., Kämper, J. and Kahmann, R. (2009) Physical-Chemical Plant-Derived Signals Induce Differentiation in Ustilago maydis. Molecular Microbiology, 71, 895-911. http://dx.doi.org/10.1111/j.1365-2958.2008.06567.x

[68] Brachmann, A., Weinzierl, G., Kämper, J. and Kahmann, R. (2001) Identification of Genes in the $b W / b E$ Regulatory Cascade in Ustilago maydis. Molecular Microbiology, 42, 1047-1063. http://dx.doi.org/10.1046/j.1365-2958.2001.02699.x

[69] Heimel, K., Scherer, M., Vranes, M., et al. (2010) The Transcription Factor Rbf1 Is the Master Regulator for $b$-Mating Type Controlled Pathogenic Development in Ustilago maydis. PLoS Pathogens, 6, Article ID: e1001035.

[70] Snetselaar, K.M. and Mims, C.W. (1992) Sporidial Fusion and Infection of Maize Seedlings by the Smut Fungus Ustilago maydis. Mycologia, 84, 193-203. http://dx.doi.org/10.2307/3760250

[71] White, D.G. (1999) Compendium of Corn Diseases. 3rd Edition, APS Press, St. Paul.

[72] Brachmann, A., Schirawski, J., Müller, P. and Kahmann, R. (2003) An Unusual MAP Kinase Is Required for Efficient Penetration of the Plant Surface by Ustilago maydis. EMBO Journal, 22, 2199-2210. http://dx.doi.org/10.1093/emboj/cdg198

[73] Mueller, O., Kahmann, R., Aguilar, G., Trejo-Aguilar, B., Wu, A. and de Vries, R.P. (2008) The Secretome of the Maize Pathogen Ustilago maydis. Fungal Genetics and Biology, 45, S63-S70. http://dx.doi.org/10.1016/j.fgb.2008.03.012

[74] Gold, S.E. and Kronstad, J.W. (1994) Disruption of Two Genes for Chitin Synthase in the Phytopathogenic Fungus Ustilago maydis. Molecular Microbiology, 11, 897-902. http://dx.doi.org/10.1111/j.1365-2958.1994.tb00368.x

[75] Xoconostle-Cázares, B., León-Ramírez, C. and Ruiz-Herrera, J. (1996) Two Chitin Synthase Genes from Ustilago 
maydis. Microbiology, 142, 377-387. http://dx.doi.org/10.1099/13500872-142-2-377

[76] Xoconostle-Cázares, B., Specht, C.A., Robbins, P.W., Liu, Y.L., León, C. and Ruiz-Herrera, J. (1997) Umchs5, a Gene Coding for a Class IV Chitin Synthase in Ustilago maydis. Fungal Genetics and Biology, 22, 199-208. http://dx.doi.org/10.1006/fgbi.1997.1014

[77] Garcerá-Teruel, A., Xoconostle-Cázares, B., Rosas-Quijano, R., et al. (2004) Loss of Virulence in Ustilago maydis by Umchs6 Gene Disruption. Research in Microbiology, 155, 87-97. http://dx.doi.org/10.1016/j.resmic.2003.11.005

[78] Weber, I., Assman, D., Thines, E. and Steinberg, G. (2006) Polar Localizing Class V Myosin Chitin Synthases Are Essential during Early Plant Infection in the Plant Pathogenic Fungus Ustilago maydis. Plant Cell, 18, 225-242. http://dx.doi.org/10.1105/tpc.105.037341

[79] Fernández-Álvarez, A., Elías-Villalobos, A. and Ibeas, J.I. (2009) The O-Mannosyltransferase PMT $_{4}$ Is Essential for Normal Appressorium Formation and Penetration in Ustilago maydis. Plant Cell, 21, 3397-3412. http://dx.doi.org/10.1105/tpc.109.065839

[80] Ruiz-Herrera, J., Robledo-Briones, M. and Martínez-Soto, D. (2013) Experimental Pathosystems as a Tool for the Identification of Virulence Factors in Pathogenic Fungi. In: Deshpande, M. and Ruiz-Herrera, J., Eds., Biotechnology: Beyond Borders, CSIR-National Chemical Laboratory, Pune, 30-38.

[81] Kämper, J., Kahmann, R., Bölker, M., et al. (2006) Insights from the Genome of the Biotrophic Fungal Plant Pathogen Ustilago maydis. Nature, 444, 97-101. http://dx.doi.org/10.1038/nature05248

[82] Doehlemann, G., Van der Linde, K., Assmann, D., Schwammbach, D., Hof, A., Mohanty, A., Jackson, D. and Kahmann, R. (2009) Pep1, a Secreted Effector Protein of Ustilago maydis, Is Required for Successful Invasion of Plant Cells. PLoS Pathogens, 5, Article ID: e100029.

[83] Hemetsberger, C., Herrberger, C., Zechmann, B., Hillmer, M. and Doehlemann, G. (2012) The Ustilago maydis Effector Pep1 Suppresses Plant Immunity by Inhibition of Host Peroxidase Activity. PLoS Pathogens, 8, Article ID: e1002684. http://dx.doi.org/10.1371/journal.ppat.1002684

[84] Doehlemann, G., Reissmann, S., Assmann, D., Fleckenstein, M. and Kahmann, R. (2011) Two Linked Genes Encoding a Secreted Effector and a Membrane Protein Are Essential for Ustilago maydis-Induced Tumour Formation. Molecular Microbiology, 81, 751-766. http://dx.doi.org/10.1111/j.1365-2958.2011.07728.x

[85] Banuett, F. and Herskowitz, I. (1996) Discrete Developmental Stages during Teliospore Formation in the Corn Smut Fungus, Ustilago maydis. Development, 122, 2965-2976.

[86] León-Ramírez, C.G., Cabrera-Ponce, J.L., Martínez-Espinoza, A.D., Herrera-Estrella, L., Méndez, L., Reynaga-Peña, C.G. and Ruiz-Herrera, J. (2004) Infection of Alternative Host Plant Species by Ustilago maydis. New Phytologist, 164, 337-346. http://dx.doi.org/10.1111/j.1469-8137.2004.01171.x

[87] Méndez-Morán, L., Reynaga-Peña, C.G., Springer, P.S. and Ruiz-Herrera, J. (2005) Ustilago maydis Infection of the Non-Natural Host Arabidopsis thaliana. Phytopathology, 95, 480-488.

[88] Martínez-Soto, D., Robledo-Briones, A.M., Estrada-Luna, A. and Ruiz-Herrera, J. (2013) Transcriptomic Analysis of Ustilago maydis Infecting Arabidopsis Reveals Important Aspects of the Fungus Pathogenic Mechanisms. Plant Signaling \& Behavior, 8, Article ID: e25059. 